\author{
OLEKSANDER DZEBAN, \\ Yaroslav Mudryi National Law University (Kharkiv, Ukraine) \\ e-mail:a_dzeban@ukr.net, ORCID 0000-0002-2075-7508
}

OLENA ALEKSANDROVA,

Borys Grinchenko Kyiv University (Kyiv, Ukraine)

e-mail: o.aleksandrova@kubg.edu.ua, ORCID 0000-0003-0030-1367

NATALIIA VINNIKOVA,

Borys Grinchenko Kyiv University (Kyiv, Ukraine)

e-mail:n.vinnikova@kubg.edu.ua, ORCID0000-0002-5162-4150

\title{
AXIOLOGICAL PORTRAIT OF INFORMATION SOCIETY
}

\begin{abstract}
The urgency of the issue is determined by an extent social discussion about the advantages and disadvantages of information process itself and application to the diverse social spheres, its problems and threatens. The main range of the problems is connected with the constant transformation and social variability, consequently with a change of worldview's field of a person. The advantages of information society are traditionally connected with the constant development, creativity, freedom and discoveries of new ways of personal realization and communication possibilities. According to a principle of post-non-classical methodology, the authors study a problem of the value transformations in conditions of information society and determine the crucial contexts of infosocialgenesis: a context of networked coordination, ethical context and symbolic context (namely, virtualization and mythologizing of information space). The realities of modern society form various even diametrically opposed values that lead to complete devaluation of each value and deprive a worldview of its principle of consolidation are considered in the issue. The authors describe the mechanisms of person's networked coordination and demonstrate that their action (constructive and destructive) facilitates in the general process of experience enrichment which is gained via a multiplicity and simultaneity of virtual practices in different spheres (simuclarization) and often mistakenly presented as a real experience of a person. The ethical transformations of information society are considered to be closely connected with an issue of personal social stability which is not often aware of the freedom limits in information space. The symbolic context of infosociogenesis in the form of virtualization and mythologizing is characterized by the creation and social inquiry of cultural forms which are produced by virtual patterns of the reality (simulacrums).
\end{abstract}

Key words: networked society; virtual; axiological information; infologem; hedonism.

Introduction

The intensive character of social postindustrial transformations is embodied into the procedures and mechanisms of generation, transmission and absorption of knowledge. According to an exponential growth "the secondary" knowledge and information in relation to a person are applied to a circulation; the fact implies a problem of knowledge desubjectivation in the light of losing additional objective features as well as personal mental sense. The rapid growth of information and knowledge volume in postindustrial society has transformed it into independent and autonomous process which has accepted a character of social unwieldy and further dependence of individual senses from personal knowledge. The stages' rotation from rapid intellectual re-orientation to valued one is a result of knowledge brevity and temporality of our internal images of the reality. A principal peculiarity of information epoch is in the existing ways of communication which are basically based on the procedures of information transmission.

Modern society is signified by replication instead of intellectual product creation and demonstrates a sense of preconditions of abovementioned phenomenon of knowledge desubjectivation.

The presented analysis of scientific studies proves the great concern for scientists that traditional senses are lost or changed, and the reality are totally under simuclarization. The intellectuals from all countries have considered the issue about an influence of information space on personal valued system in modern social and philosophical discussions for many years (Gellman, 2005; Harris, 2007; Žižek, 2011; Ihnatenko, 2011; Baeva, 2014; Floridi, 2014; Fomin, 2018 Antonenko, Chursin, 2019). On the other hand, the limits of freedom and selfrealization in information space are tried to be determined in accordance with a vector's change of information and technical characteristics of social development (Brin, 1998; Stock, 2003; Korableva, 2015). M. Castells (2000; 2007) wrote a lot about social and cultural phenomena that transformed spiritual and social demands into technological development and responded to new technological solutions via social and cultural breakthrough. The following authors (Chiriac, 2013; Dzeban, Zdanenko, 2013; Kulya, 2016) mention a connection between tech- 
nology and axiology in modern culture, an ideal formation that eliminates any moral scientific and technological neutrality. Simultaneously, the various contexts of social and valued connections, for instance a context of networked coordination, ethical and symbolic contexts should be considered for clear conceptual depiction of new forms of worldviews' interconnection with modern valued settings.

The aim of the issue is to prove the determined influence of worldviews' transformations on valued changes in information society.

\section{Methods}

The axiology of post-industrial society is often identified as a post-modern state. Consequently, post-non-classical, post-modern methodology with the polycentric, relativism (worldview's relativism, ethical, cultural, etc.), plurality, the principle of a rhizome, the principle of nomadic, etc. are applied for a description.

A worldview situation in information society is determined as limited or rather unlimited relativism by the philosophers who study the social and cultural spheres. In the styles mixture determination in post-modern culture which ruins the cultural paradigmatic unity, the researchers highlight the positive moment in everything that happens with the insurance of cultural plurality which leads to consciousness change in less academic way and facilitates in creation of unlimited freedom and mind flexibility, opens creative possibilities that improve personal development.

\section{Results and Discussion}

$A$ person under development of networked coordination

A process of development of networked coordination is traditionally related to the row of social and cultural breakthrough. The networked forms begin to change the mass society by modifying social connections that transform a society into fragmented and uneven that causes a change in "monolithic" audience. A vast number of horizontal information sources have become predominant instead of the vertical ones in information society. The numerous horizontal information flows have a destructive influence on a social structure and social hierarchies, as they are not differentiate them anymore, but eliminate the boarders of social institutes, groups, communities (Sitkevich, 2011: 51). Such transformations facilitate the development of social networks and networked culture. It is mistakenly perceived that a society returns to the past at the unstructured syncretic stage. Actually, this dissipative structure releases creational energy of human; atomizes a society in a way of further complicating structure creation. Simultaneously, the social and cultural space is being much more complicated, namely information space of social and cultural opportunities of knowledge coding and replication is added, moreover, virtual space, which is a total space of simulaclars that are incorporated into the ordinary daily reality by the networked culture carriers, is included. Human comfort has profoundly increased with the total informatization of all spheres of life, as we have mentioned earlier (Danylian and other, 2018; Dzeban, 2013; 2014; Dzeban and Zhdanenko, 2013), there are negative displays in parallel at the global, local and individual levels. An activity change in the external environment leads to stagnation of internal spiritual field: a great amount of given information and contacts that are rapidly expanding cause a feeling of instability, in addition human's interests are further shifted from the spiritual sphere of life to material one.

The scientists in the sphere of ethical philosophy mention that a modern person responds to a moral pressure from the developing informatization that cause the loss of spiritual guidance and a kind of internal world destruction. For instance, a Romanian scientist $\mathrm{H}$. C. Chiriac considers that the new technologies are morally neutral and a main threat is in their incapability to offer a new code of behavior to humanity. Due to the usage and spreading of the new technologies in networked society, the human relationships "between life and death, time and space" are blurred (Chiriac, 2013: 121). The Ukrainian scientist A. Husyev highlights two types of changes determined by hazardous influence of information space on individual consciousness.

Firstly, there are the changes of psyche, mental state of a human, an indicator of which can be a loss of adequate world's depiction in a human consciousness and his attitude to a world. This can lead to a transfer from the higher necessities (in self-realization, social recognition) to the lower ones (physiological, connected with life support). Secondly, there are transformations in the values, attitudes, guidelines, worldviews that are the reasons of anti-social deeds and can be a threat to the whole society and state (Husyev, 2012: 73).

A human of modern civilization is considered as an active person, a transformational activity of whom is the main human purpose. Furthermore, an active ideal of human attitude to the nature is expanded into the sphere of social relations. Rational thinking aimed at external world consideration and knowledge usage for tools' production for increasing of their effectiveness and nature understanding in the light of objective reality with the existed regularities having known what a person can take a control under them is typical for such society. "It is wellknown, - writes A.J. Toynbee, - that the individuals and communities whose efforts are completely concentrated on the process of transformation of the raw material into the light, heat, movement and other mass consumption objects, can think that any discover or exploitation of natural resources is a valuable activity despite the value of the results of the processes for humanity" (Toynbee, 1996: 14). The standard technological mass culture has appeared deprived of any national peculiarities and separated from humanism heritage. The relations of personal dependence have not dominated anymore and have been subordinated to the social connections; as a result the new valued systems have been formed on their ground.

Plurality and complicated mosaic of life styles and attitudes become the main characteristics of information society. "Everything should be tasted, tested, namely various national cuisine as well as culture, science, religion, sexuality should be practically considered. A number of applied practices can tend to infinity. The practical possibilities are discovered via magazines and TV commercials. An emerged necessity is not always displayed as an urgent desire, or specific advantage. It is a diffused interest in the most cases" (Sitkevich, 2011: 5354). Owing to information accessibility, post-modernism eclectically combines all achievements and cultural values from all historical epochs, it easily combines them, manipulates with such complicated elements as a mosaic way of images', knowledge' and values' presentation. Nowadays, a concept of "personality" is completely substituted by a concept of "mask" (Savchenko, 2011), which means that a separate aspect of the phenomenon has become a phenomenon itself. 


\section{Ethical transformations}

The modern social state has begun to depend on moral, cultural and political codes chosen by individuals who created the particular society. The development of information society as a global phenomenon due to its character, international information networks' establishment shifts the sphere of all ways of social life's acceptance. The source of the highest social truth in traditional and industrial types of society was a revelation, or a social feeling derived from a special vocational mission of a clan, nation to maintain a unique right society. The information technologies and systems borders' expansion has cardinally changed the state. It is connected with the fact that the process of social relations of informatization does not objectively depend on subjective aims and national interests. The individuals recognize each other and determine their social identity according to a type of information field where they are in a modern situation. There are the mass contradictions between the external individual belongings to a particular ethos or state and the internal solidarity with cultural standards which do not coincide with national tradition.

The reality of modern society is based on the maximal diversity which forms various equals and even sometimes diametrically opposed values that is led to their devaluation. Such opposed polarity deprives a worldview of its consolidation principle, some universal and absolute supremacy values. It is unthinkable to claim sacrifice of the interests, time and income for an idea of common good from a modern man in the situation, as the idea is rather abstract. The phenomena as an idea of mind, truth and justice, the cultivated values (of absolute and taboo in particular), a concept of honor have lost their urgency. As a result, an information epoch demands new ethic norms, the theoretical bases of which are offered by, for example (Fuchs, Bichler, Raffl, 2009; Guogis, 2010; Spence, 2011).

The dominance of concepts with collective social color is a distinguished feature of a mature industrial society; hence the moral of information society is expressed by "Self" primacy over extra-personal social values as well as their union in one universal concept - "style" ("image") that is something external, applied, and easily changeable owing to a personal environment. People change their attitudes as easy as they change their suit, consequently ethical relativism creates a world without basic values and ideas.

Nevertheless, the lost moral principles claim to be replaced and the scientists determine several ways of common social values renewal in a worldview's system, the wide spread of them are aggression, a game with illusions, body-centrism (Karpovets, 2013; Shkil, 2015). The ways are determined by the following reasons. Any aggression strengthening is connected with the loss of universal values which is accompanied by a process of violence universalization as a phenomenon that is maximally deprived of any values. A man "drown" in social and cultural space of an information society, demonstrates his sensitiveness and even defenselessness against a flow of ideas, thoughts, points of view, etc. Everything abovementioned destabilizes citizens' mental state as well as leads to various crimes that are performed with extreme cruelty.

Regarding to the death concept, a modern person has lost any hope to explain it (in order to accept its existence) as a result he tries to forget about it. Owing to the vast number of documentaries, feature films and TV-shows with the images of death, the issue has become an ordinary one and lost its deep personal roots.

\section{Virtualization and mythologizing of relations}

An information society becomes similar to virtual reality and can be described via its characteristics (Ivanov, 2002: 29-34). Visualization is any substitution of a reality with its simulation with the general application of virtual reality logic in this case. The result of such borders' retouching of human activity becomes emotional instability, a desire of being hidden behind a game, a wish of rejecting any hierarchy, careless fun. Moreover a center of internal spiritual world has shifted to a cult of body as an obvious and easy-accepting value. The main features of bodycentered views are a transition from a word to a body, from intellectual spiritual activity to physical activity, from verbal image to picture image, from rational senses to "a new archaic" where at the center of any mentality is body, flesh. Furthermore, the high priority placed on the catastrophes, apocalyptical episodes, in general, to all that can destroy a body and everything that secure physical satisfaction (sexual freedom, drugs, entertainments that lead to various emotions). The modern commercials have strengthened such tendencies, actively exploited and cultivated the images and practices of a body (Karpovets, 2013; Shkil, 2015).

The most objective circumstance of a man upbringing is information accessibility which is considered in the light of transparency, maximal information saturation, intensification of information flows and their rapid change in a modern world. All people are consumers of mass information in information society. Nowadays, almost everyone is connected to information networks as to the household networks. Radio, TV, newspapers, telephone, personal computers supply information to every family. A user of information has transformed to a voracious consumer of information.

Individual, grouped and mass consciousness has increasingly been influenced by aggressive information influences that harm psychological and moral health of the citizens, ruin moral norms of life and destabilize social situation. Obtained information influences on a personal emotional state, causes a response and provokes some actions. The common group interests are crucial for group consciousness that are recognized by the group members and reflected in their individual consciousness in the form of norms of behavior, interests' satisfaction, achievement of the goals, and readiness to contractions. The conservative and dynamic parts are important in the mass consciousness. The first component is created via the amount of common social interests of the objects, recognized cultural, moral and social values that intensify socially acceptable rules of behavior and a way of life via their availability to any unions, associations against the potential threatens to their interests, traditions and rituals. The dynamic part of mass consciousness is created via the collection of information reflection about the socially important events and it obtains a corresponded emotional evaluation of the events. We should apply to a category of "infologema" (a term introduced by V. Kogan) that implies mistaken information used for creating a substitution of basic facts by the artifacts in order to understand the mechanisms of information influence on mass, group and individual consciousness. The infologems appear as a result of unconscious mistakes or conscious targeted manipulative influences. They are able to self-rebuilding, renewing, increasing or integrating into the systems. The infologems have influenced on a man for an unlimited period, they are parts of thesaurus dictionaries in particular and information fund in general, and consequently they take part into worldview formation. The means and me- 
thods of the manipulative influence on a person have rapidly enhanced and applied everywhere. A success is based on creation of a wrong impression that a person controls his behavior and any his choice is performed on the base of a rational analysis of a situation according to his will. Infologems form the stable stereotypes of individual and social behavior, and are able to disorient even the whole generation. The vast majority of social and psychological infologems has in the base a unity of two personal features: xenophobia, anger for a stranger and a strong desire to find an enemy who is a cause of all calamities.

Infologems as any virtual myths are ideological, political and social; they substitute true information remaining a true from the first glance; however they are false in the core sense. As a result the various disinformation successfully forms the standards of inadequate behavior, distracts from unpleasant social reality, eliminates frustration and secures the visibility of psychological comfort (Kogan, 1993: 10-39). The modern social myths have initially changed people in order to have an opportunity of regulation and control of their actions. People have become the victims of the myths without any serious resistance. The myths incorporated in consciousness are able to change a whole structure of a worldview or substitute a holistic worldview by a fragmented one that leads to destructed understanding of the reality and even to mental disorders.

Mythologizing of information society is determined by three worlds' intertwining: a world of objective reality, information world and symbolic (virtual world), the fact illuminates culture as "the symbolic universe". The main parameters of two last worlds are information and communication that are proved by the majority of studies to be not only the main type of activity, but the basic strategical resource which forms a worldview and human consciousness in information society.

Having underlined a role of information in social management, M. McLuhan emphasized that the mass communications played a crucial role in the process of social consciousness mythologizing. An amount of semantic information (produced and distributed by special organizations) transmitted by the technical channels increases much more faster than an amount of semantic information obtained by a person from direct experience and personal communication in the conditions of information epoch. A myth is a product of mass production, a principle of mass consciousness organization, furthermore TV is considered by McLuhan as the main mythproducer in the modern post-industrial society at the end of the $20^{\text {th }}$ century (McLuhan, 2005).

The social, political, art, religious myths are rapidly produced in large numbers within information space. They combined with social facts perform a real influence on society despite their illusory character. A new myth has transformed into a mean of social mobilization and manipulation of social consciousness. Modern culture has intensively produced myths that are aimed at connection and distribution of social energy, saturation of mass consumers' enquiries, for instance to stimulate mass products' selling as it is done by the commercials, to create an appealing image of a politician or a pop star, to keep views' attention by any action or "soap opera" with the help of TV industry (Dzeban, 2017).

A new myth is presented in a type of false mobilizing structure that is able to adopt a person and people to the social reality, having creating an image of truth and psychological comfort in the persons' minds. For instance, any TV-commercial widely incorporated into mass cons- ciousness has a great influence on cultural and information space that is created by it on the base of a principle of the reality mythologizing. Information included into a myth obtains perceptional and sensitive peculiarity; it is easily memorized, presented a life space of a modern person with the high degree of aesthetics. Nevertheless, it leaves a man in his illusions at best, or considers him as an object of various manipulations, including political ones, at worst.

It should be mentioned that information society is a kind of social myth which attractiveness is in usage of scientific and technological advances such as information and computer-based communications. The glamorous power of information society's myth is so strong that neither technologists (it is unreasonable to reject the powerful commercial), nor humanists (nobody guarantees a place of honor in a new hypothetical society for them) cannot resist it. A greater demand in information society is applied to the technologists-intellectuals who are oriented on a personal success and not on the intellectuals. The information needs of the intellectuals were satisfied by the global electronic networks instead of books.

A loss of privacy is typical for activity of information networks that creates a base for a process of personal unification and depersonalization. Information openness is not a barrier for individualization; furthermore, it facilitates to introduce unprecedented mass standards into human consciousness.

A person has inspired by some ideas that are generated by the well-known heroes during the time his activity. The scientists observe that a place of the heroes is occupied by so-called quasi-subjects that are virtual collected stereotypes actively cultivated by political and trade commercials. As Ivanov rightly asserts, there is a quasisubject in the commercials who pretends to make a right choice (Ivanov, 2002). To sum up, the stereotypes are formed from health life provision to social orientation and motivation where the modern heroes - quasi-subjects preach the main modern virtue - consumption.

The predominant form of communication was axial communication (that connected a sender and a receiver of a clear addressed message) and consequently, a sphere of communication was a sphere of the personaloriented signals circulation within traditional and industrial societies. The situation has changed in post-industrial society: the collectively oriented signals determine a personal communication sphere. A person in a postmodern age is a man who exists in a system of retail communication (that does not have any strictly determined communication subjects). The new environment of communication is formed by the modern mass culture, media, commercial, etc. Nobody addresses personally to a person anymore. It is common to address to the whole groups, subcultures, the carriers of a unified style ("Dear audience", "Ladies and Gentlemen"). A person has frequently communicated with a quasi-subject, instead of the real people, a virtual presentation of a common type of a person who contains the numerous features of different people (Ihnatenko, 2011).

The theoreticians of post-industrial era are based on the idea that in the ordinary consciousness owing to the objective circumstances, the main life issues are nonurgent within the borders of person's existence (a man should not work constantly to maintain his life, bloodline reproduction has ceased to be an unconditional dominant). The special uniqueness of a modern situation is in an issue of the meaning of life that should be equal to a question: "How should we spend the mass of our free time?" (Sitkevich, 2011: 64). 
If "freed" from the work people obtained from society all necessary means of living, the phenomenon can be positively evaluated. However, there is another side. A man has lost work willingly or unwillingly, in addition he has lost the meaning of his life centered into the constant labor to maintain own life and his family existence. The scientists of post-industrial era perceive a way out of the tough situation in a change of the main activity type: study instead of work. Long-life personal development should become the base on a personal formation in post-industrial society. A. Shaff offered to put efforts into creation of new personal types - Homo Studiosus and Homo Universalis. A universal human is considered as a well-educated person who is able to change a profession and as a result, his position in social division of labor. Moreover he mentions that a modern man of information society should constantly meet a deadline, he is in a position of a player who is run of time to make the necessary moves to change human nature. Everything requires the huge preparation and consideration that even have not begun yet; nevertheless, "the time will not wait if we do not want to create social pathology" (Shaff, 1995: 319-320). Thus, A. Shaff recognizes a threat of personal internal state in the new conditions.

The existence of the meaning of life is a positive value as it determines human mental condition. The modern policy of consumption contains threats to this value and to the humans' mental conditions. A threat is connected with inherited unemployment into the structure of post-industrial society as a result of the common automatization and robotization. The work has always been a symbol of personal and social usefulness, an instrument of social self-identification, a way to a relevant social status without which a stimulus has disappeared and a person has become indifferent to all social aspects. As the main "instinct" of a modern person is consumption, consequently an empty space generated after the death of the life's meaning is filled with the consumption of the products from entertaining industry. The bright kaleidoscope of the illusory games is able to disorient completely or partially man's consciousness. A person has gradually lost a meaning of reality without serious and responsible work. The surrounding world is mosaic and attractive, consequently, the attention splits and a personal worldview does not present a coherent harmonious system.

The global information infrastructure creates the technological base for the unity of intellectual abilities and spiritual power of all humanity. Nevertheless, it is a crucial factor of "information expansion" where the main role is given to the new means of mass communication. They broaden the existed cultural codes due to the ready-made formulas developed by information technologies. Power and influence belong to the people who are able to create new cultural codes that are used by the society for displaying the reality and making the conscious decisions in information society. The virtual power is completely real, as according to the measure of its concentration, it transforms into the ability of the certain people to impose their will on the society. The international elite, that coordinate the networked society, is deeply integrated into the space of information flows presented predominantly financial, social, political and personal information. The measure of the elite incorporation into the space of international information flows influences on its independence, namely the higher the level of incorporation, the less level of dependence from national culture, state and any societies.

Information and technological environment opens the broad possibilities for the new types of activity as well as it contains the potential threats of a structure of personality deformation and damage of the ways of his social adaptation. Human intelligence is challenged by the information acceptance shift: from book culture to display one. The issues of abstract thinking and memory are questionable. The popular manner of misspelling among the youth within internet communication causes a steady decrease of literacy level; thus, a man cannot remember the right spelling of a word. The special situation is with the computer games as a product of the most dynamic spheres of the modern technological industry that perform the significant influence on human consciousness and worldview.

A man has to endure such amount of information that after having filled the natural limits, a person has been frustrated and lost his value. The information culture where the wheat is mixed with the chaff is called "information trash" by Umberto Eco. A person should be able to regulate the quality and flow of information that influence on his mental condition, mood and consciousness. As a perspective of social humanization, U. Eco predicts that in the nearest future people are filtering the information; if they do not learn to accept the necessary information, the accessibility of it will be senseless.

An intellectual filter has become an effective instrument of rational activity in the circumstances when information fund stored by humanity has many times exceeded person's abilities. Applying purposely, it is able to reduce information loads on a person via releasing his psychological and physiological resources. Furthermore, any determination of the procedures of intellectual filtering within information greatly increases their effectiveness.

\section{Conclusions}

In conclusion, a social transition to a new kind of informatization created the new tendencies in the social values formation. The contexts, considered in the issue, provided the basis for the following conclusions.

1. Networked personal coordination is a complex of the networked mechanisms of communication, personal involvement into the virtual public space, its networked positioning and possibilities for the virtual and social grouping for acquiring some identities or achieving some goals. The action of the described mechanisms creates the incredible variety of personal experience which is obtained via multiplicity and simultaneity of virtual practices in different spheres of life (simulaclarization) and may mistakenly be accepted as true personal experience. The networked coordination has constructive and destructive character. The destructive character can occur in the situation when a person is not able to correlate an information flow from a global network with the moral and value principles that are established by the previous education, social tradition, etc.

2. The ethical transformations of information society are closely connected with a sphere of personal social stability that is not aware of freedom borders in information society. The reasons of this phenomenon are the following: a) a person is not ready emotionally and intellectually to this freedom; b) a person has not formed the corresponding algorithms of structuring and critical consideration of information that have to be relevant to the established axiological complexes.

3. Virtualization and mythologizing of relations create a new worldview's context - infosociogenesis, within which a transformation of life's and worldview's positions and even the mental process itself can be followed. The peculiarity of the context is a social demand of cultural forms that produce virtual patterns of the reality (simulaclars). Nowadays, these cultural forms are the lawmakers of the senses. 


\section{REFERENCES}

Antonenko, T., Chursin, M. (2019). On the Eve of the Future: the Values Sign Change. Philosophy and Cosmology (Filosofiya i kosmologiya), 23: 82-91.

Baeva, L. V. (2014). Antinomies of Values under Conditions of Information Age. In R. Luppicini (Ed.), Evolving Issues Surrounding Technoethics and Society in the Digital Age (pp. 198-212). Hershey, PA: IGI Global. DOI: https://doi.org/10.4018/978-1-46666122-6.ch013

Brin, D. (1998). The Transparent Society: Will Technology Force Us to Choose Between Privacy and Freedom? Perseus, Reading, MA

Castells, M. (2000). Informatsionnaya epokha: ekonomika, obshchestvo i kultura (The Information Age: Economics, Society and Culture). Moscow: GU HSE, 608 p. (In Russian)

Castells, M. (2007). Internet-galaktyka. Mirkuvannya shchodo Internetu, biznesu i suspilstva (Internet galaxy. Reflections on the Internet, Business and Society). Kyiv: Vyd-vo "Vakler", 304 p. (In Ukrainian)

Chiriac, H. C. (2013). Scientific and Religious Imaginary in the Knowledge Society. European Journal of Science and Theology, 9(1), 111-122. Retrieved from http://www.ejst.tuiasi.ro/Files/35/ vxzc012wsa99zxc.pdf

Danylian, O. H., Dzeban, O. P., Zhdanenko, S. B. and other (2018). Suspilstvo, lyudyna, pravo: dosvid filosofsko-pravovoho osmyslennya. Kharkiv: Pravo, 350 p. (In Ukrainian)

Dzeban, O. P. (2013). Sotsialni perspektyvy genezy informatsiynykh protsesiv. Hileya: naukovyy visnyk, 74 (№ 7): 167-169. (In Ukrainian)

Dzeban, O. P. (2014). Manipulyatyvnyy kharakter informatsiynoho seredovyshcha suchasnoho suspilstva. Informatsiya i pravo. 3 (12): 3-12. (In Ukrainian)

Dzeban, O. P. and Zhdanenko, S. B. (2013). Do problemy moralno-etychnykh aspektiv informatsiynoho suspilstva. Visnyk Natsionalnoho universytetu "Yurydychna akademiya Ukrayiny imeni Yaroslava Mudroho". Seriya: Filosofiya, filosofiya prava, politolohiya, sotsiolohiya, 5 (19): 104-114. (In Ukrainian)

Floridi, L. (2014). The Fourth Revolution: How the Infosphere Is Reshaping Human Reality. Oxford: Oxford University Press.

Fomin, M. V. (2018). Transindustrialism-Upcoming Social Reality. Voprosy filosofii, (1), 42-54.

Fuchs, C., Bichler, R. M., \& Raffl, C. (2009). Cyberethics and co-operation in the information society. Science and engineering ethics, 15(4), 447. DOI: https://doi.org/10.1007/s11948-0099138-1

Gellman, R. (2005). The digital person: Technology and privacy in the information age. Government information quarterly, 22 (3): 530-532. DOI: https://doi.org/10.1016/j.giq.2005.01.005

Guogis, A. (2010). To refrain from capitalism or to improve it? The importance of equity during crisis. FILOSOFIJA-SOCIOLOGIJA, 21(2), 83-91.

Harris, John. (2007). Enhancing Evolution: The Ethical Case for Making Better People. Princeton University Press, PrincetonNJ.

Husyev, A. A. (2012). Nebezpeky, sformovani v suspilstvi za rakhunok rozvytku informatsiynykh tekhnolohiy. Biznes Inform. 4: 72-75. (In Ukrainian)

Ihnatenko, V. (2011). Samotniy kvazisubyekt u epokhu postmodernu: krytyka hlobalizovanoho suspilstva. Visnyk Natsionalnoho aviatsiynoho universytetu. Seriya: Filosofiya. Kulturolohiya, 2: 88-93. (In Ukrainian)

Ivanov, D. V. (2002). Virtualizatsiya obshchestva: Versiya 2.0. St.Petersburg: PV, 224 p. (In Russian)

Karpovets, M. (2013). Tilo, moda, identychnist: postmoderni konfihuratsiyi. Naukovi zapysky Natsionalnoho universytetu "Ostrozka akademiya". Filosofiya. 2013. Issue. 14: 156-160. (In Ukrainian)

Kogan, V.Z. (1993). Kachestvo informatsii i mir infologem (fragmenty teorii). In: Problemy informatsionnogo vzaimodeystviya. Novosibirsk, 10-39. (In Russian)
Korableva, E. (2015). Freedom of the information space. Is it a reality or illusion? Anthropological Measurements of Philosophical Research, 7, 124-129. DOI: http://dx.doi.org/10.15802/ampr2015/ 43690

Kulya, A. E. (2016). Informatsiyne suspilstvo yak produkt rozvytku informatsiynykh tekhnolohiy. Derzhava ta rehiony. Seriya: Sotsialni komunikatsiyi, 3: 36-39. (In Ukrainian)

McLuhan, M. (2005). The Gutenberg Galaxy: The Becoming of the Human Print. Moscow: Academic Project, 495 p. (In Russian)

Savchenko, A. A. (2011). Postmodernizm yak sotsiokulturne yavyshche. Visnyk Kharkivskoyi derzhavnoyi akademiyi kultury. Issue 33: 196-202. (In Ukrainian)

Shaff, A. (1995). Kuda vedet doroga? In: Filosofiya istorii. Antologiya. Mosow: Aspekt-Press, pp. 311-321. (In Russian)

Shkil, L. L. (2015). Tilotsentryzm yak nove yavyshche Postmodernu. Hileya: naukovyy visnyk. Issue 94: 169-172. (In Ukrainian)

Sitkevich, N. V. (2011). Osobennosti transformatsii nravstvennykh tsennostey $v$ usloviyakh informatsionnogo obshchestva. Novomoskovsk, 139 p. (In Russian)

Spence, Edward H. (2011). Information, knowledge and wisdom: groundwork for the normative evaluation of digital information and its relation to the good life. Ethics and Information technology, 13: 261-275. DOI: https://doi.org/10.1007/s10676-0119265-7

Stock, G. (2003). Redesigning humans: Choosing our children's genes. Profile Books, London, UK.

Toynbee, A. J. (1996). Postizheniye istorii (Understanding History). Moscow: Progress: Kultura, 606 p. (In Russian)

Žižek, S. (2011). Living in the End Times. London: Verso, $416 \mathrm{p}$.

\section{LIST OF REFERENCES LINKS}

Гусєв А. А. Небезпеки, сформовані в суспільстві за рахунок розвитку інформаційних технологій. Бізнес Інформ. 2012. № 4. С. $72-75$.

Дзьобань О. П. Маніпулятивний характер інформаційного середовища сучасного суспільства. Інфрормація і право. 2014. № 3 (12). C. 3-12.

Дзьобань О. П. Соціальні перспективи ґенези інформаційних процесів. Гілея: науковий вісник. 2013. Випуск 74 (№ 7). C. $167-169$.

Дзьобань О. П., Жданенко С. Б. До проблеми моральноетичних аспектів інформаційного суспільства. Вісник Національного університету "Юридична академія України імені Ярослава Мудрого". Серія: Філософрія, фрілософрія права, політологія, соціологія. 2013. Вип. 5 (19). С. 104-114.

Иванов Д. В. Виртуализация общества: Версия 2.0. Санкт-Петербург: ПВ, 2002. 224 с.

Ігнатенко В. Самотній квазісуб'єкт у епоху постмодерну: критика глобалізованого суспільства. Вісник Національного авіаційного університету. Серія: Філософрія. Культурологія. 2011. № 2. C. 88-93.

Карповець М. Тіло, мода, ідентичність: постмодерні конфігурації. Наукові записки Національного університету "Острозька академія". Філософія. 2013. Вип. 14. С. 156-160.

Кастельс М. 2000. Информационная эпоха: экономика, общество и культура. Москва: ГУ ВШЭ, 608 с.

Кастельс М. Інтернет-ґалактика. Міркування щодо Інтернету, бізнесу і суспільства; [пер. з англ.]. Київ: Вид-во "Ваклер", 2007. 304 с.

Коган В. 3. Качество информации и мир инфрологем (фрагменты теории). Проблемы инфрормационного взаимодействия. Новосибирск, 1993. С. 10-39.

Куля А. Е. Інформаційне суспільство як продукт розвитку інформаційних технологій. Держава та регіони. Серія: Соціальні комунікації. 2016. № 3. С. 36-39.

Маклюэн М. Галактика Гутенберга: становление человека печатающего. Москва: Академический Проект, 2005. 495 с

Савченко А. А. Постмодернізм як соціокультурне явище. Вісник Харківської державної академії культури. 2011. Вип. 33. C. $196-202$. 
Ситкевич Н. В. Особенности трансформации нравственных ценностей в условиях информационного общества: этико-философский анализ: дис. ... канд. филос. наук. Новомосковск, 2011. 139 с.

Суспільство, людина, право: досвід філософсько-правового осмислення: монографія / О. Г. Данильян, О. П. Дзьобань, С. Б. Жданенко та ін.; за ред. О. Г. Данильяна. Харків Право, 2018. 350 с.

Тойнби А. Дж. Постижение истории: Сборник. Москва: Прогресс: Культура, 1996. 606 с.

Шафф А. Куда ведет дорога? Философия истории. Антология. Москва: Аспект-Пресс, 1995. С. 311-321.

Шкіль Л. Л. Тілоцентризм як нове явище Постмодерну. Гілея: науковий вісник. 2015. Вип. 94. С. 169-172.

Antonenko T., Chursin M. On the Eve of the Future: the Values Sign Change. Philosophy and Cosmology (Filosofiya i kosmologiya). 2019. no 23, pp. 82-91.

Baeva L. V. Antinomies of Values under Conditions of Information Age. In R. Luppicini (Ed.), Evolving Issues Surrounding Technoethics and Society in the Digital Age. 2014. pp. 198-212. Hershey, PA: IGI Global. DOI: https://doi.org/10.4018/978-1-46666122-6.ch013

Brin D. The Transparent Society: Will Technology Force Us to Choose Between Privacy and Freedom? Perseus, Reading, MA, 1998.

Chiriac H. C. Scientific and Religious Imaginary in the Knowledge Society. European Journal of Science and Theology. 2013. no 9 (1), pp.111-122. Retrieved from http://www.ejst.tuiasi.ro/Files/35/ vxzc012wsa99zxc.pdf
Floridi L. The Fourth Revolution: How the Infosphere Is Reshaping Human Reality. Oxford University Press, Oxford, 2014.

Fomin M. V. Transindustrialism-Upcoming Social Reality. Voprosy filosofii. 2018. No 1, pp. 42-54.

Fuchs C., Bichler R. M., \& Raffl C. Cyberethics and co-operation in the information society. Science and engineering ethics, 2009. 15(4), 447. DOI: https://doi.org/10.1007/s11948-009-9138-1

Gellman R. The digital person: Technology and privacy in the information age. Government information quarterly. 2005. Vol. 22, issue 3, pp. 530-532. DOI: https://doi.org/10.1016/j.giq.2005.01.005

Guogis A. To refrain from capitalism or to improve it? The importance of equity during crisis. FILOSOFIJA-SOCIOLOGIJA. 2010. 21(2), 83-91.

Harris J. Enhancing Evolution: The Ethical Case for Making Better People. Princeton University Press, Princeton-NJ, 2007.

Korableva E. Freedom of the information space. Is it a reality or illusion? Anthropological Measurements of Philosophical Research, 2015. no 7, pp. 124-129. DOI: http://dx.doi.org/10.15802/ ampr2015/43690

Spence Edward H. Information, knowledge and wisdom: groundwork for the normative evaluation of digital information and its relation to the good life. Ethics and Information technology. 2011. no 13, pp. 261-275. DOI: https://doi.org/10.1007/s10676011-9265-7

Stock G. Redesigning humans: Choosing our children's genes. Profile Books, London, UK, 2003.

Žižek S. Living in the End Times. London: Verso, 2011. 416 p.

Олександр Дзьобань,

Національний юридичний університет імені Ярослава Мудрого (м. Харків, Украӥна)

e-mail:a_dzeban@ukr.net,ORCID0000-0002-2075-7508

Олена Александрова,

Київський університет імені Бориса Грінченка (м. Київ, Украӥна)

e-mail: o.aleksandrova@kubg.edu.ua, ORCID 0000-0003-0030-1367

Наталія Віннікова,

Київський університет імені Бориса Грінченка (м. Київ, Украӥна)

e-mail:n.vinnikova@kubg.edu.ua,ORCID0000-0002-5162-4150

\section{АКСІОЛОГІЧНИЙ ПОРТРЕТ ІНФОРМАЦІЙНОГО СУСПІЛЬСТВА}

Актуальність статті зумовлена триваючою в суспільстві дискусією про переваги та недоліки інформатизації та інформаційного суспільства, його проблеми і ризики. Основне коло проблем пов'язано 3 постійною трансформацією та соціальною нестабільністю, а отже, й зміною світоглядного поля особистості; переваги інформаційного суспільства прийнято пов'язувати з постійним розвитком, творчістю, свободою і відкриттям нових шляхів реалізації особистості та їі комунікаційних можливостей. Використовуючи принципи постнекласичної методології, автори досліджують проблему ціннісних змін в умовах інформаційного суспільства і виділяють при цьому деякі важливі контексти інфосоціогенезу: контекст мережних координацій, етичний контекст та символічний контекст (віртуалізація та міфологізація інформаційного простору). Обґрунтовується, що реалії сучасного суспільства формують численні, часом діаметрально протилежні, цінності, що призводить до знецінення кожної з них і позбавляє світогляд консолідуючого принципу. Автори описують сукупність механізмів мережевої координації особистості і показують, що їх дія (конструктивна і деструктивна) уможливлює надзвичайне урізноманітнення досвіду людини, який набувається через множинність і одночасність віртуальних практик у різних сферах життя (симулякризація) і часто хибно видається за справжній досвід особи. Показано, що етичні трансформації інформаційного суспільства найбільше пов'язані 3 темою соціальної стійкості особистості, яка часто не усвідомлює межі своєї свободи у інформаційному просторі, а символічний контекст інфосоціогенезу у вигляді віртуалізації та міфологізації, характеризується створенням та соціальною запитаністю культурних форм, що продукують віртуальні патерни реальності (симулякри).

Ключові слова: мережеве суспільство; віртуальне; аксіальна інформація; інфологема; гедонізм.

(c) Dzeban Oleksander, Aleksandrova Olena, Vinnikova Nataliia

Надійшла до редакції: 27.08.2019

Прийнята до друку: 16.09.2019

ISSN 1728-9343 (Print)

ISSN 2411-3093 (Online)

SKHID No. 5 (163) September-October 2019 